\title{
One Tambon One Product Implementation Strategies In Malang
}

\section{Raya}

\author{
Gunarianto $^{\mathrm{a}}$. Mulyono ${ }^{\mathrm{b}}$ \\ ${ }^{\mathrm{a}}$ Faculty of Economic, University of Widya Gama Malang, Jl. Borobudur No.35, Blimbing, Malang City, East Java, 65141, Indonesia \\ ${ }^{\mathrm{b}}$ Faculty of Economic, University of Widya Gama Malang, Jl. Borobudur No.35, Blimbing, Malang City, East Java, 65141, Indonesia
}

Correspondence Author: Gunarianto, Faculty of Economic, University of Widya Gama Malang, Jl. Borobudur No.35, Blimbing, Malang City, East Java, 65141, Indonesia

Received date: 15 August 2019, Accepted date: 30 September 2019, Online date: 10 October 2019

Copyright: () 2019 Gunarianto and Mulyono, This is an open-access article distributed under the terms of the Creative Commons Attribution License, which permits unrestricted use, distribution, and reproduction in any medium, provided the original author and source are credited.

\begin{abstract}
The objectives of this research are: 1) to understand leading sectors that positively contribute to economic growth; and 2) to comprehend One Tambon One Product (OTOP) implementation strategies in Malang Raya. Research object is Micro, Small \& Medium Enterprises in Malang Raya. Data analysis is done with various techniques such as long list of leading commodities, Analytical Hierarchy Process (comprising activities such as building hierarchy, conducting survey and analyzing survey result), and Focus Group Discussion. Result of research provides few findings. Leading commodities of Malang City are derived from three kinds of trading system, namely, traditional trade (for vegetables, fishes and its kinds), large-scale trade, and mixed trade. Malang Regency's leading commodities produced mostly by industries, such as food industry, wood industry, metal industry, and plait/pottery/ceramic industry. Batu City's leading commodities are emanated from wholesale market, star and jasmine hotels, natural and artificial tourism, food and beverage, and wet and mixed markets. The implementation of OTOP Program in Malang Raya, however, is not fully supported by local government in various levels. Local government, therefore, is suggested to play significant roles regarding to this matter, such as by identifying potential products that can be administered in OTOP Program, giving business advices to producers, maintaining packaging quality, and controlling product design to make sure that products are attractive in the market. Local government can also do some supporting activities such as facilitating marketing channel, managing market chain, and providing access to internet. Supporting organizations must be made available, such as supporting agent for business development or that for technical assistance, and also coordinator forum across institutions. Those supporting organizations may later be helpful in implementing many strategies for MSMEs development, and the suggested strategy in this context is product differentiation.
\end{abstract}

Keywords: One Tambon One Product, Leading Commodity, Strategy

\section{INTRODUCTION}

Industry 4.0 is a strategy to create the digital-based Five Principles (Pancasila) Economy. It is consistent with national road map's direction toward Making Indonesia 4.0 in order to increase national industry performance through innovation and utilization of the latest technology. National priority set to pursue this direction is by empowering Micro, Small \& Medium Enterprises (MSMEs). Almost seventy percents of Indonesian entrepreneurs are MSMEs entrepreneurs. Government, therefore, must build commitment to support MSMEs entrepreneurs, and it can be realized by building what so-called e-commerce platform. It is synchronous with the local government's strong will to make local economic development strategy aligned with people favor to achieve the aspired welfare. Proper policy concerning local economic development shall enable local entrepreneurs to see opportunity and later exploit it for increasing productivity and expanding export.

The development of local leading products or sectors through One Tambon One Product (OTOP) has many goals, such as: to improve the marketability of local leading products at local or global markets; and to improve quality and added-value of the products that later may increase its competitiveness over imported products. Activities concerning OTOP must be coordinated 
Citation: Gunarianto and Mulyono., One Tambon One Product Implementation Strategies In Malang Raya. Australian Journal of Basic and Applied Sciences, 13(10): 66-72. DOI: 10.22587/ajbas.2019.13.10.9

with the Ministry of Cooperative and Small \& Medium Enterprises, and shall also involve cooperatives and MSMEs with the increase of people income as its ultimate goal.

Result of previous review shows that there are many MSMEs in Malang Raya that have been established naturally with their own uniqueness without local government intervention. There are MSMEs centres for leather crafts in Malang Regency. Some MSMEs centres for soy cake (tempe) chips have been established in Malang City. Several cassava processing centres are found in Batu City. The development of MSMEs in Malang Raya is not widely different from its counterparts in other regions. Most of them are not yet professional, with low competing ability, without clear management, and only concerning family livelihood.

This research is a comprehensive follow-up of previous studies. Micro, Small \& Medium Enterprises, poverty eradication and competing ability have been the topics examined by many previous studies such as Tuti Hastuti et.al. (2007), Tuti Hastuti et.al. (2008), Gunarianto et.al. (2008), Gunarianto and Nasri (2011), and Tuti Hastuti et.al. (2013, 2014), Mulyono (2015, 2016), Gunarianto et.al. (2017), and Gunarianto et.al. (2018).

Gunarianto and Nasri (2011) had conducted a study in Pasuruan City and found that competing for ability is an accumulation of various capabilities and cooperations obtained by MSMEs organization. Implementing political decision only is not enough because participation and support of all stakeholders are always needed. The critical study carried out by Saputro et.al. (2010) demonstrated that main issues challenging MSMEs are limited resources, lack of financial capacity, manual business operation, low information technology, and separate business operations. Further study by Tuti Hastuti et.al. (2013) found that the most suitable model to deal with problems confronted by MSMEs in Malang Raya is by providing consultation and training. Still with same topic, next study by Tuti Hastuti et.al. (2014) had proposed 5 (five) development programs to actualize MSMEs progress, namely: (i) human resource development program; (ii) MSMEs' development program; (iii) self-supported capitalization program; (iv) business development program; and (v) versatile information provisioning program.

\section{METHOD OF RESEARCH}

Some analytic stages must be passed by before determining whether One Tambon One Product is proper or not to be implemented in local MSMEs. The analytic frame of this determination is depicted in the following.

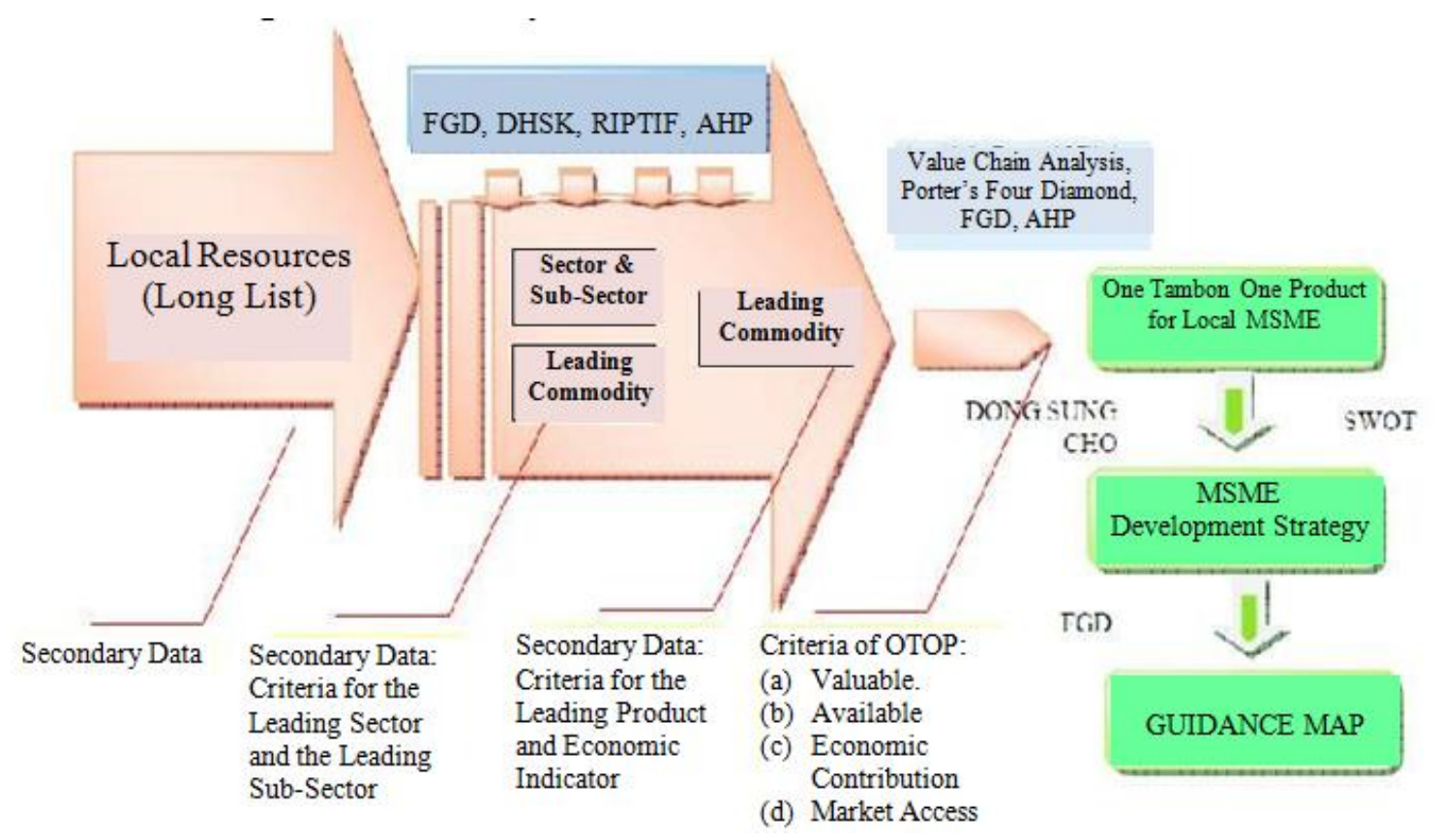

Fig. 1: The Analytical Frame of One Tambon One Product Determination.

Research coverage was Malang Raya. Data collection method was done by field survey, Participatory Research Appraisal (PRA), Focus Group Discussion (FGD) and workshop seminars. Data analysis technique was using survey subjected to MSMEs in each region studied. Quantitative and qualitative data were obtained from the Office of Industry, Trade and Cooperatives at each region studied. Primary data were acquired from the questionnaire given to MSMEs entrepreneurs.

\section{RESULT OF RESEARCH}

Concerning with added-value aspect, Malang Raya actually has a lot of potential commodities that can be processed into derivative products with greater added-values. But, almost all these commodities are only sold to consumers, which signifies that the producers are seemingly not creative and less care to quality. In the marketing aspect, leading commodities in Malang Raya are actually been available for local, regional or export markets. The problem is that information about market are still limited. The product variety is always unique and its promotion is always a massive campaign. 
Citation: Gunarianto and Mulyono., One Tambon One Product Implementation Strategies In Malang Raya. Australian Journal of Basic and Applied Sciences, 13(10): 66-72. DOI: 10.22587/ajbas.2019.13.10.9

Regarding local image aspect, Malang Raya is not only known for its leading products but also recognized for its education and tourism potentials. Those supposed to be attractive for investors, consumers and tourists. With respect to local culture aspect, Malang Raya community is known by characteristics of industry, education, trade, and tourism, and most importantly, has good kinship aspiration. People in Malang Raya always take some efforts to gain better living standard and use their times as productive as possible.

In relation with investors perspective concerning local reputation aspect, it can be said that conditions, richness, and natural location of Malang Raya are truly potential to make this region an investment destination. Building reputation needs sustainable encouragement, and it can be done by providing and perfecting infrastructures to produce business climate that is supportive to investment.

\section{Economic Development in Malang Raya}

The contribution of economic sectors in Malang Raya to the growth of Current Price-Based Gross Regional Domestic Income (GRDI) is illustrated in few tables. The summary of each region studied (Malang City, Malang Regency, and Batu City) is given below the table.

Table 1. Current Price-Based GRDI of Economic Sectors in Malang City from 2015 to 2018

\begin{tabular}{|c|c|c|c|c|c|}
\hline Category & Sector & 2015 & 2016 & 2017 & 2018 \\
\hline A & Agriculture, Forestry and Fishery & $2.23 \%$ & $0.08 \%$ & $0.04 \%$ & $0.76 \%$ \\
\hline $\mathrm{B}$ & Mining and Excavation & $-3.58 \%$ & $5.58 \%$ & $0.35 \%$ & $-3.17 \%$ \\
\hline $\mathrm{C}$ & Processing Industry & $2.51 \%$ & $1.95 \%$ & $3.67 \%$ & $2.71 \%$ \\
\hline $\mathrm{D}$ & Electric and Gas Supplies & $-0.01 \%$ & $4.73 \%$ & $3.84 \%$ & $2.85 \%$ \\
\hline $\mathrm{E}$ & Water Supply, Trash \& Waste Management, and Recycle & $3.71 \%$ & $4.92 \%$ & $7.02 \%$ & $5.22 \%$ \\
\hline $\mathrm{F}$ & Construction & $5.18 \%$ & $6.74 \%$ & $7.24 \%$ & $6.39 \%$ \\
\hline G & $\begin{array}{c}\text { Wholesale \& Retail Tradings and Reparation of Cars \& } \\
\text { Motorcycles }\end{array}$ & $6.56 \%$ & $6.31 \%$ & $5.60 \%$ & $6.16 \%$ \\
\hline $\mathrm{H}$ & Transportation and Warehousing & $6.83 \%$ & $7.47 \%$ & $9.25 \%$ & $7.85 \%$ \\
\hline $\mathrm{I}$ & Accommodation and Food \& Beverage Provisioning & $8.12 \%$ & $7.89 \%$ & $8.34 \%$ & $8.12 \%$ \\
\hline $\mathbf{J}$ & Information and Communication & $8.14 \%$ & $9.09 \%$ & $8.02 \%$ & $8.42 \%$ \\
\hline $\mathrm{K}$ & Finance and Insurance Services & $7.13 \%$ & $7.89 \%$ & $2.77 \%$ & $5.93 \%$ \\
\hline $\mathrm{L}$ & Real Estate & $7.25 \%$ & $7.41 \%$ & $4.01 \%$ & $6.23 \%$ \\
\hline $\mathrm{M}, \mathrm{N}$ & Company Services & $8.77 \%$ & $7.13 \%$ & $5.03 \%$ & $6.98 \%$ \\
\hline $\mathrm{O}$ & $\begin{array}{l}\text { Government Administration, Defense and Mandatory Social } \\
\text { Services }\end{array}$ & $3.72 \%$ & $1.71 \%$ & $3.24 \%$ & $2.89 \%$ \\
\hline $\mathrm{P}$ & Education Services & $8.31 \%$ & $7.92 \%$ & $7.50 \%$ & $7.91 \%$ \\
\hline $\mathrm{Q}$ & Health and Social Activity Services & $9.95 \%$ & $8.27 \%$ & $7.57 \%$ & $8.60 \%$ \\
\hline $\mathrm{R}, \mathrm{S}, \mathrm{T}, \mathrm{U}$ & Other Services & $3.88 \%$ & $4.37 \%$ & $4.28 \%$ & $4.17 \%$ \\
\hline & GRDI & $5.61 \%$ & $5.61 \%$ & $5.69 \%$ & $5.71 \%$ \\
\hline
\end{tabular}

Based on current price in 2018, the sector in Malang City with the highest contribution to GDRI growth is Sector of Health and Social Activity Services with $8.60 \%$, followed by Sector of Information and Communication with $8.42 \%$. A sector with the lowest contribution to GDRI growth is Sector of Mining and Excavation with $-3.17 \%$, followed by Sector of Agriculture, Forestry and Fishery with $0.76 \%$. The economic growth rate of Malang City tends to rise. In 2015, the rate reaches 5.61\% and then rises with year, precisely $5.61 \%$ in $2016,5.69 \%$ in 2017 , and $5.71 \%$ in 2018 . Monetary circulation is dominated by monies expended by government and middle-to-high class individuals who invest in Malang City.

Table 2. Current Price-Based GRDI of Economic Sectors in Malang Regency from 2014 to 2018

\begin{tabular}{|c|c|c|c|c|c|c|}
\hline Category & Sector & 2014 & 2015 & 2016 & 2017 & 2018 \\
\hline A & Agriculture, Forestry and Fishery & $18.15 \%$ & $17.96 \%$ & $17.50 \%$ & $16.82 \%$ & $15.39 \%$ \\
\hline $\mathrm{B}$ & Mining and Excavation & $2.10 \%$ & $2.04 \%$ & $1.96 \%$ & $1.91 \%$ & $1.85 \%$ \\
\hline $\mathrm{C}$ & Processing Industry & $29.99 \%$ & $30.20 \%$ & $30.33 \%$ & $30.48 \%$ & $30.88 \%$ \\
\hline $\mathrm{D}$ & Electric and Gas Supplies & $0.08 \%$ & $0.08 \%$ & $0.07 \%$ & $0.08 \%$ & $0.07 \%$ \\
\hline $\mathrm{E}$ & ater Supply, Trash \& Waste Managemen & $0.10 \%$ & $0.10 \%$ & $0.10 \%$ & $0.10 \%$ & $0.10 \%$ \\
\hline $\mathrm{F}$ & Construction & $12.65 \%$ & $12.63 \%$ & $12.83 \%$ & $13.02 \%$ & $13.38 \%$ \\
\hline $\mathrm{G}$ & \& Retail Tradings and $\mathrm{R}$ & $18.51 \%$ & $18.48 \%$ & $18.66 \%$ & $19.04 \%$ & $19.47 \%$ \\
\hline $\mathrm{H}$ & Transportation and Warehousing & $1.14 \%$ & $1.17 \%$ & $1.18 \%$ & $1.22 \%$ & $1.27 \%$ \\
\hline $\mathrm{I}$ & ccommodation and Food \& Be & $3.10 \%$ & $3.17 \%$ & $3.26 \%$ & $3.34 \%$ & $3.45 \%$ \\
\hline $\mathrm{J}$ & Information and Comm & $4.01 \%$ & $3.97 \%$ & $3.96 \%$ & $3.96 \%$ & $3.99 \%$ \\
\hline $\mathrm{K}$ & Finance and Insurance Services & $1.72 \%$ & $1.72 \%$ & $1.73 \%$ & $1.77 \%$ & $1.73 \%$ \\
\hline $\mathrm{L}$ & Real Estate & $1.31 \%$ & $1.35 \%$ & $1.33 \%$ & $1.33 \%$ & $1.35 \%$ \\
\hline $\mathrm{M}, \mathrm{N}$ & Company Services & $0.36 \%$ & $0.36 \%$ & $0.36 \%$ & $0.37 \%$ & $0.37 \%$ \\
\hline $\mathrm{O}$ & Government Administration, Defense and Mandatory Social Services & $1.90 \%$ & $1.90 \%$ & $1.89 \%$ & $1.84 \%$ & $1.84 \%$ \\
\hline
\end{tabular}


Citation: Gunarianto and Mulyono., One Tambon One Product Implementation Strategies In Malang Raya. Australian Journal of Basic and Applied Sciences, 13(10): 66-72. DOI: 10.22587/ajbas.2019.13.10.9

\begin{tabular}{|c|c|c|c|c|c|c|}
\hline $\mathrm{P}$ & Education Services & $2.43 \%$ & $2.41 \%$ & $2.40 \%$ & $2.27 \%$ & $2.39 \%$ \\
\hline Q & Health and Social Activity Services & $0.57 \%$ & $0.56 \%$ & $0.55 \%$ & $0.55 \%$ & $0.55 \%$ \\
\hline $\mathrm{R}, \mathrm{S}, \mathrm{T}, \mathrm{U}$ & Other Services & $1.90 \%$ & $1.90 \%$ & $1.89 \%$ & $1.90 \%$ & $1.92 \%$ \\
\hline & GRDI & \multicolumn{5}{|c|}{$100.0 \% 100.00 \% 100.00 \% 100.00 \% 100.00 \%$} \\
\hline
\end{tabular}

A sector in Malang Regency with the biggest contribution to Current Price-Based GRDI is Sector of Processing Industry with an increase from $29.99 \%$ in 2014 to $30.88 \%$ in 2018. Second place is occupied by Sector of Wholesale \& Retail Tradings and Reparation of Cars \& Motorcycles with a rising trend from $18.51 \%$ in 2014 to $19.47 \%$ in 2018. The economic growth of Malang Regency is mostly affected by Micro, Small \& Medium Enterprises. The presence of MSMEs has strongly influenced people welfare. Of Current Price-Based GRDI that reaches totally 95 trillion Indonesian Rupiahs, the half of it, which is 47 trillions, is contributed by MSMEs. The economic growth rate in Malang Regency indicates an increasing trend, precisely with $5.27 \%$ in 2015 to $5.30 \%$ in 2016. Consecutively, the rate ascends in 2017 and 2018 by $5.43 \%$ and $5.57 \%$.

Table 3. Current Price-Based GRDI of Economic Sectors in Batu City from 2014 to 2018

\begin{tabular}{|c|c|c|c|c|c|c|}
\hline Category & Sector & 2014 & 2015 & 2016 & 2017 & 2018 \\
\hline $\mathrm{A}$ & Agriculture, Forestry and Fishery & $16.41 \%$ & $16.30 \%$ & $16.20 \%$ & $15.52 \%$ & $15.19 \%$ \\
\hline B & Mining and Excavation & $0.20 \%$ & $0.19 \%$ & $0.18 \%$ & $0.17 \%$ & $0.16 \%$ \\
\hline $\mathrm{C}$ & Processing Industry & $4.56 \%$ & $4.66 \%$ & $4.65 \%$ & $4.78 \%$ & $4.80 \%$ \\
\hline $\mathrm{D}$ & Electric and Gas Supplies & $0.04 \%$ & $0.04 \%$ & $0.04 \%$ & $0.04 \%$ & $0.04 \%$ \\
\hline $\mathrm{E}$ & Water Supply, Trash \& Waste Management, and Recycle & $0.18 \%$ & $0.18 \%$ & $0.17 \%$ & $0.17 \%$ & $0.16 \%$ \\
\hline $\mathrm{F}$ & Construction & $10.82 \%$ & $11.28 \%$ & $11.54 \%$ & $11.77 \%$ & $11.92 \%$ \\
\hline $\mathrm{G}$ & Wholesale \& Retail Tradings and Reparation of Cars \& Motorcycles & $18.39 \%$ & $18.02 \%$ & $18.08 \%$ & $18.41 \%$ & $18.40 \%$ \\
\hline $\mathrm{H}$ & Transportation and Warehousing & $1.31 \%$ & $1.31 \%$ & $1.28 \%$ & $1.28 \%$ & $1.29 \%$ \\
\hline I & Accommodation and Food \& Beverage Provisioning & $11.38 \%$ & $11.64 \%$ & $12.06 \%$ & $12.37 \%$ & $12.57 \%$ \\
\hline $\mathrm{J}$ & Information and Communication & $6.48 \%$ & $6.35 \%$ & $6.19 \%$ & $5.96 \%$ & $5.81 \%$ \\
\hline K & Finance and Insurance Services & $3.97 \%$ & $4.06 \%$ & $3.99 \%$ & $3.84 \%$ & $3.85 \%$ \\
\hline $\mathrm{L}$ & Real Estate & $2.92 \%$ & $2.93 \%$ & $2.83 \%$ & $2.81 \%$ & $2.83 \%$ \\
\hline $\mathrm{M}, \mathrm{N}$ & Company Services & $0.49 \%$ & $0.48 \%$ & $0.46 \%$ & $0.45 \%$ & $0.44 \%$ \\
\hline $\mathrm{O}$ & Government Administration, Defense and Mandatory Social Services & $2.49 \%$ & $2.46 \%$ & $2.40 \%$ & $2.40 \%$ & $2.39 \%$ \\
\hline $\mathrm{P}$ & Education Services & $4.09 \%$ & $3.95 \%$ & $3.83 \%$ & $3.75 \%$ & $3.83 \%$ \\
\hline Q & Health and Social Activity Services & $0.81 \%$ & $0.80 \%$ & $0.77 \%$ & $0.76 \%$ & $0.75 \%$ \\
\hline $\mathrm{R}, \mathrm{S}, \mathrm{T}, \mathrm{U}$ & Other Services & $15.47 \%$ & $15.34 \%$ & $15.35 \%$ & $15.52 \%$ & $15.58 \%$ \\
\hline & GRDI & \multicolumn{5}{|c|}{$100.00 \% 100.00 \% 100.00 \% 100.00 \% 100.00 \%$} \\
\hline
\end{tabular}

Among economic sectors in Batu City, the biggest contribution to Current Price-Based GDRI is given by Sector of Wholesale \& Retail Tradings and Reparation of Cars \& Motorcycles. This sector shows an increasing trend from $18.39 \%$ in 2014 to $18.40 \%$ in 2018. The second-biggest contribution is shown by Sector of Other Services with a disposition to increase, precisely from $15.47 \%$ in 2014 to $15.58 \%$ in 2018 . Some factors are supporting economic upsurge in Batu City. Among others is that tourist resort is increasing in numbers every year, which later, it produces great number of tourist visitors. Throughout 2018, tourist visit to Batu City has reached 5.6 million visitors. This number exceeds the target set by the Office of Tourism for Batu City, which stands as 5.2 millions visitors. Batu City Government has built infrastructures that support tourism, which include improvement of road class and revitalization of rural area. The economic growth rate of Batu City shows an increasing trend from $6.69 \%$ in 2015 to consecutively $6.61 \%, 6.65 \%$ and $6.71 \%$ in 2016,2017 and 2018.

Back to Malang Raya context, value chain analysis was conducted in this research to understand value creation process. Business environment analysis was also carried out to identify factors affecting competing ability, and the analysis process was operated with the Porter Diamond approach. Diagnosis map on competing ability shows four determinant factors, which respectively are resource input, business strategy \& competition, demand, and supporting organization. These four factors are interdependent and related to one another.

Resource input and business strategy \& competition are conditions strongly affected by government decision in ascertaining whether the government must support or constrain the development of targeted MSMEs. If these two conditions are dominant, then strategy to empower targeted MSMEs is by making government policy that supports MSMEs development and also by conditioning social environment that facilitates business environment. In the other hand, demand and supporting organization are conditions greatly affected by business opportunity in targeted MSMEs. When business environment is dominated by these conditions, then strategy to empower targeted MSMEs is by promoting intensively MSMEs business to increase bargaining position and also by optimizing the capacity of organizations that support MSMEs (or minimizing the constraint). Optimization effort can be done among others by innovatively exploiting the existing opportunities. Overall, these two strategies above shall be comprehensive. 
Citation: Gunarianto and Mulyono., One Tambon One Product Implementation Strategies In Malang Raya. Australian Journal of Basic and Applied Sciences, 13(10): 66-72. DOI: 10.22587/ajbas.2019.13.10.9

Result of analysis indicates that leading commodities with the highest contribution to GRDI of Malang Raya are consecutively ordered as follows: (1) Malang City: its leading commodities derive from traditional trade on vegetables, fish and its kinds (wet market); commodities from large-scale trade (wholesale); and commodities from mixed trade (garment, electronic, and others); (2) Batu City: its leading commodities emanate from vegetables/wholesale trade, natural \& artificial tourism, and hotel as one of tourist destinations; and (3) Malang Regency: its leading commodities come from food industry, wood industry, metal industry and plait/pottery/ceramic industry.

\section{Strategy and Result of Evaluation and Monitoring on the Implementation of One Tambon One Product Model}

The implementation of One Tambon One Product model in Malang Raya is involving a strategy called product differentiation. In this strategy, it shall be ensured whether natural resource potentials are really able to support the production of leading commodities with reliable competing ability. The potentials are always vital because it may give a brand image of unique products to MSMEs in foreign market. Such understanding can motivate MSMEs to feel pride in certain commodities and then use certain symbol, jargon and others to promote it. To make product differentiation strategy successful, the following requirements shall be considered:

1) Community groups are a potential human resource. These groups usually have base capitals such as skill, work ethos and proclivity toward cooperation. Those capitals can be gained by granting funds for training and by giving consultation \& mentoring for human resource development. Training must be given free of charge and conducted on hands-on practice format that emphasizes on sustainability. Fostering activity can be integrated with soft loaning.

2) Local Government of Malang Raya needs to establish the Office of MSMEs Promotion as liaison agency to develop a partnership with higher educational institutions. The purpose of this partnership is to increase MSMEs' bargaining position, to enable MSMEs in capturing market opportunity and to allow MSMEs to penetrate new market, which later increases their global competing ability.

3) Local Government can provide capital grants in form of a loan (at modest interest rate without physical collateral, but only with one or two individual guarantors) and also revolving fund for the sake of development of household and handicraft industries. Eligibility criteria for receiving capital grants are as follows: (a) Entrepreneurs have ever attended training or received grants for marketing, production process, product development and business practice; (b) Business are considered reliable to receive grants; (c) Enterprises have adequate assets; and (d) Enterprises employ 50 workers in maximum.

4) Local Government of Malang Raya needs to facilitate community with various technology instruments, which among others is websites as the electronic-based source of information for trade interest (e-commerce).

5) Solid support and coordination from local government institutions of Malang Raya and East Java Province are needed, and it must be implemented with chief executive officer (CEO) style. It must be noted that One Tambon One Product Program is born from policies and strategies set by government. This Program, therefore, is monitored, evaluated and revitalized thoroughly through various policy instruments to obtain optimum success level. For instance, no less than 25 government institutions and 12 subordinate agencies under the State Ministry of Cooperatives and MSMEs are involved into OTOP Program implementation.

6) Economic development plans shall be consistently based on people welfare, and the plans must be implemented in gradual manner. For example, One Tambon One Product implementation strategies are mostly designed by involving three stakeholders, precisely, government, private and non-government organizations (NGO)/other local organizations (therefore, designing process is called as cluster development). The participation of those stakeholders will ensure that people welfare has been considered.

7) Low-and-middle class entrepreneurs must be targeted for receiving grants. Through this arrangement, Micro, Small \& Medium Enterprises shall then be considered as the backbone of national economic.

8) Good coordination among entrepreneurs is still affected by leadership and direct control by community on OTOP Program. The controller community may comprise producers and local entrepreneurs who have actively selected and determined leading commodities.

Focus Group Discussion (FGD) has invited relevant experts to discuss One Tambon One Product (OTOP) implementation strategy. Result of this discussion is described as follows: (1) Stakeholders must aware and understand anythings about OTOP; (2) Rural or regional potentials must be exploited; (3) Products with high added-value must be set into priority; (4) Business experiments shall be made sustainable and considered as the part of innovation and development of leading products; and (5) Human resource with talents and creativity must be empowered and then institutionalized as entrepreneurship culture.

There are four steps that can be taken in the future to make One Tambon One Product (OTOP) campaign becoming more effective. First is that people must be made aware of and understand about OTOP. Second is that relevant policies shall be made to foster community talents. The third is to find, select and develop the selected products, and then to re-create them into unique products with high competing ability. The final or the fourth is to market these products into national and global scopes. Any local 
Citation: Gunarianto and Mulyono., One Tambon One Product Implementation Strategies In Malang Raya. Australian Journal of Basic and Applied Sciences, 13(10): 66-72. DOI: 10.22587/ajbas.2019.13.10.9

governments in Malang Raya can use OTOP to substantiate their economic vision. There is one variant of this vision, namely "Triple Track Strategy" that consists of three elements, which are pro growth, pro employment and pro poor.

\section{Impact of OTOP Model Implementation on MSMEs in Malang Raya}

The implementation of One Tambon One Product (OTOP) approach to the development of industrial sectors or leading products in Malang Raya has been giving some positive impacts. These are described as follows:

1. It facilitates Micro, Small \& Medium Enterprises in building collaborative network (value chain), which is later enabling them not only to make production process more efficient but also to create added-values for all business units. This collaboration can strengthen the power of economic institutions in certain region.

2. The collaboration will produce collective agenda in making marketing concept, in planning product branding, and in sharpening regional identity for leading products. All these activities surely help MSMEs to obtain recognition at national or international levels.

3. It eases MSMEs to achieve economic of scale, which then allows them to reach economical and technical efficiencies and attain production sustainability, which later gives them high productivity.

4. It may guide MSMEs in attaining their best competency level on a certain leading product in a certain region.

5. It can reduce MSMEs worriness about competition and make them focusing more on building "trust" and "cooperation" with other business actors.

6. Micro, Small \& Medium Enterprises can use public infrastructures provided to them in efficient and effective ways, either in form of hardware or software.

\section{Local Government of Malang Raya in OTOP Model Implementation}

The implementation of One Tambon One Product (OTOP) Program is not strongly supported by local government in various levels in Malang Raya. Dealing with this issue, therefore, local government is required to materialize several roles, which include: identifying potential products to be eligible for OTOP Program; giving business advices to producers; controlling package quality; and monitoring product design to make it attractive for domestic and export markets. Moreover, local government needs to take supportive actions for marketing. It may involve properly managing market chain and providing internet system to expand market and distribution channels of the products. Three criteria exist for selecting products eligible for OTOP Program. First is that products must be unique and be the priority for certain public taste. Second is that products have high standard for quality. Lastly, the third is that products are derived from the works of reliable workers who can run the production process in fast and precise manners.

\section{CONCLUSION}

Local government of various levels in Malang Raya seems to be less supportive to the implementation of One Tambon One Product Program. Actually, some roles can possibly be played by local government regarding to this matter, such as by identifying potential products to be eligible for OTOP Program; giving business advices to producers; controlling package quality; and monitoring product design to make it attractive for domestic and export markets. Besides, marketing support seems low still. Local government does not yet take necessary measures to manage market chain properly and to provide internet system that can expand market and distribution channels of the products. Despite all these weaknesses, in Malang Raya, supporting organizations are already available, such as those that support business development or those that give technical aids. However, these organizations work in partial, and therefore their performance is suboptimum. Besides, there is no coordination yet among governing institutions concerning legality of these organizations.

\section{ACKNOWLEDGMENTS}

Research team confers unforgettable gratitude to DP2M Dikti for the funding provided to this research for 3 years. Superb thanks are also given to Local Government of Malang Raya, LPPM of Malang Widyagama University, and MSMEs Entrepreneurs for their assistances in the completion of this research.

\section{REFERENCES}

Adirestuty, Fitranty, NidaAfifah and Ade Suyitno, 2011. Using OVOP Approach for Jacking Up Local Products by Empowering Local Association of College Students in the Campus Business Incubator, UPI Bandung. 
Citation: Gunarianto and Mulyono., One Tambon One Product Implementation Strategies In Malang Raya. Australian Journal of Basic and Applied Sciences, 13(10): 66-72. DOI: 10.22587/ajbas.2019.13.10.9

Arsoowan Laeha, 2013. The Implementation of One Tambon One Product Policy to Increase People Participation in Natam District, Yala Province, Thailand. Public Administration Network. Fifth Edition. No.1, January-June. FISIP-UNAIR.

Helmsing, A.H.J., 2001. Local economic development: new generations of actors, policies and instruments. Draft paper for the Cape Town Symposium.

Astia, Dendi, 2004. Poverty Mitigation through MSME Empowerment: Some Lessons from Nusa Tenggara. Final Report of the Cooperation between Internal Affair Ministry, through its General Directorate of Local Development Fostering, and Deutsche Gesellschaftfür Technische Zusammernabeit (GTZ) GmBH.

Blakely, J., Edward, 1998. Planning Local Economic Development: Theory and Practice, Sage Publications.

Bryman, A., 1988. Quantity and Quality in Social Research, Unwin Hyman, London.

Gunarianto, M., Nasri, 2011. Review on the Compilation of Competence of Local Industries in Pasuruan City. Result of Research.

Gunarianto, SitiAsiyah and Alfiana, 2008. Review on Capital Investment Flow into MSMEs in Sector of Trade \& Service in Blitar City. Faculty of Economic, Malang Widyagama University. Result of joint research in cooperation with the Government of Blitar City.

Gunarianto, TutiHastuti and SitiAsiyah, 2008. Review on Allocation Strategy of the 2008 APBD to Accelerate IPM Improvement and Poverty Mitigation in Belu Atambua Regency. Faculty of Economic, Malang Widyagama University. Result of joint research in cooperation with the Government of Atambua City.

Gunarianto, Tuti Hastuti and Siti Asiyah, 2007. The Formulation of Policy Concept to Improve Quality of Micro \& Small Industry Centers in Blitar City. Faculty of Economic, Malang Widyagama University. Result of joint research in cooperation with the Government of Blitar City.

Gunarianto, A.T., Marjani, P.S. Endah, 2014. The Analysis of Earning Management and Earning Response Coefficient: Empirical Evidence From Manufacturing Companies Listed in Indonesian Stock Exchange. International Journal of Business and Management Invention, 3(8).

Gunarianto, A.T., Marjani and P.S. Endah, 2015. Effect of Good Corporate Governance, Motivated Behavior and Implementation of Accounting Information System on Real Behavior of Earnings Management (Study atGo Public Manufacturing Companies in Indonesian Stock Exchange). Australian Journal of Basic and Applied Sciences, 9(33): 337-345.

Gunarianto, 2016. Capital Structure and Related Problems at Financial Firms That List WithIndonesia Stock Exchange. Australian Journal of Basic and Applied Sciences, 10(9):30-38.

Gunarianto, 2016. Effect of Good Corporate Governance, Motivated Behavior, Implementation of Accounting Information System and Real Earnings Management Behavior on Company Performance (Study at Go Public Manufacturing Companies in Indonesian Stock Exchange). Australian Journal of Basic and Applied Sciences, 10(15): 92-101.

Gunarianto, 2017. The Formulation of One Tambon One Product Concept as the Effort to Empower Micro, Small \& Medium Enterprises in Designing the Strategy to Improve Their Competitive Advantage and Market Access in Welcoming ASEAN Market in Great Malang. Australian Journal of Basic and Applied Sciences, Vol. 11(15): 34-46.

Gunarianto. 2018. The Use Of One Tambon One Product Model As The Strategy to Improve Competitive Advantage And Market Access of Micro, Small And Medium Enterprises In Effort to Attain Better Development In Welcoming ASEAN Market In Great Malang. Australian Journal of Basic And Applied Sciences. Vol. 12(9): 98-106. DOI: 10.22587/ajbas.2018.12.9.17

KRI International Corp, 2004. Final Report of Study about the Capacity Building of MSE Clusters in Indonesia Republic. The Government of Indonesia Republic through the Coordinator Ministry for Economic Issue, delegating to Department of Industry and Trade, and also through the State Ministry for Cooperative and Small \& Medium Enterprises, in cooperation with Japan International Cooperation Agency. Final Report is given on March.

Maliza and Feser, 1999. Understanding Local Economic Development, Center for Urban Policy Research, New Jersey.

Modul of Participatory Local Social Development (PLSD) in Planner Version, PSKM-UNHAS-JICA Indonesia, 1-10 August 2005.

Mulyono, 2016. The Making of Finance Skimming Policy for Primary Industry Sector in MSME in East Java. Result of Research.

Mulyono, 2015. The Design of Competitive Fostering Model for MSME in Mojokerto City. Result of Research.

Neuman, W.L., 2009. Social Research Methods, Qualitative and Quantitative Approach, Ally and Bacon, Bosto Gesellschaft für Technische Zusammernabeit (GTZ). Local Economic Development, position paper (draft 2004): What Makes LED?

Nurcahyo, Rahmat, Farizal, EdwinSetiadi and Saparudin, 2012, "Determination and Development of Core Competencies for Bekasi Regency", Journal of Industrial Engineering, 13(1): 37-42.

Pasaribu, M., Sahat, 2011."Rural Agroindustry Development through OneVillageOneProduct(OVOP) Approach,Agroeconomic Research Forum, 29(1): 1-11.

Ratmono, NediHendriand Yateno, 2016. OVOP Approach to Leading Product Development Program in Lampung Province Region. ISSNPrinted 1978-6573/ISSNOnline:2477 - 300X DERIVATIVE, 10-2. 
Sajarwan, Akhmad, Muses Embang, Mofit Saptono, Abdul Mukti, ReviSumaryati, MerryLidia and PandriYani, 2009. “Developmental Study on the Program of One Village One Productin Palangka Raya City", Research \& Development Bulletin, 1(01): 3-14.

Saputro, J.W., Putu Wuri Handayani, Achmad Nizar Hidayanto and Indra Budi, 2010. "Roadmap of Research on EnterpriseResource Planning(ERP) with Focus on Small-Medium Enterprises (UKM) in Indonesia", Journal of Information Systems, 6(2): 140-145.

Sri Hermuningsih, Dewi Kusumaand Wardani, 2012. OneVillageOneProduct (OVOP) Approach to the Developmental Program for Policies Concerning Local Leading Products of IKM and MSME. Jogja Forum for Business Economy. Yogyakarta, 4159.

Sumodiningrat, 2004. The Setting of Poverty Mitigation Strategy. Article was presented at the Workshop of Experience Sharing across the Locals in Poverty Mitigation Effort. The workshop was held at Sanur Paradise Plaza Hotel, Denpasar, Bali on 2-4 July 2004. In cooperation with National Agency for Planning, World Bank, GTZ and DFID.

Triharini, Meirina, DwinitaLarasati and R.Susanto, 2012.“OneVillage One Product (OVOP) Approach for the Development of Local Handicraft Potentials: Case Study on Pottery Handicrafts in Plered District, Purwakarta Regency”. ITBJ. Vis.Art\&Des, 6(1): 28-41.

Tuti Hastuti, Alfiana and Siti Asiyah, 2014. Micro, Small and Medium Enterprise (MSME) Empowerment Model as the Effort for Peverty Eradication in Malang Raya. International Journal of Business and Management Invention (IJBMI) 3-1. Result of Competitive Bequest Research (PHB) on First Year.

Tuti Hastuti, Alfiana and Siti Asiyah, 2015. Micro, Small and Medium Enterprise (MSME) Empowerment Model as the Effort for Peverty Eradication in Malang Raya. International Journal of Business and Management Invention (IJBMI) Volume 4- Issues 1-Version 1 (January-2015 Version). Result of Competitive Bequest Research (PHB) on Second Year.

TutiHastuti, Alfiana and SitiAsiyah, 2013. Micro, Small and Medium Enterprise (MSME) Empowerment Model as the Effort for Poverty Eradication in Great Malang..Result of Competitive Bequest Research (PHB). DP2M-DIKTI 